DOI: 10.31695/IJASRE.2022.8.1.1

\title{
Simulation of a Single Phase Inverter with Unipolar Voltage Switching Using Sinusoidal Pulse Width Modulation (SPWM) Technique
}

\author{
Akuhwa T David ${ }^{1}$, Tingir T. James ${ }^{2}$ and Peter A. Akor ${ }^{3}$ \\ Department of Electrical and Electronics Engineering \\ Federal University of Agriculture \\ Makurdi, Nigeria
}

\begin{abstract}
The choice of the switching techniques used is key to good inverter performance, as it could offer reduced switching losses, generate less EMI, reduce filter size and offer better THD performance. To improve inverter performance these factors must be put into consideration. This Paper presents the Modelling, and Simulation of Single Phase Sinusoidal pulse Width Modulation (SPWM) Inverter With Unipolar Voltage Switching using the SIMULINK toolbox of MATLAB software. In this switching scheme, the high-frequency triangular carrier wave is compared with two sinusoidal modulating signals having the same amplitude and a frequency of $50 \mathrm{~Hz}$. The two sinusoids are $180^{\circ}$ out of phase. The output is used to switch the two legs of the H-bridge inverter in a complementary fashion. The results obtained from the simulation show an output with the fundamental voltage of $283.4 \mathrm{~V}$ at the frequency of $50 \mathrm{~Hz}$ and a total harmonic distortion (THD) of $64.42 \%$ when the filter was not applied. However, with the incorporation of LC filter the THD was further reduced to $2.7 \%$ at the fundamental voltage of $236.6 \mathrm{~V}$. However, Without output voltage feedback control, change in load resistance from $10 \Omega$ to $50 \Omega$ marginally increased the fundamental voltage and percentage THD up to $239.5 \mathrm{~V}$ and $4.22 \%$. The experimental setup also presents similar waveforms.
\end{abstract}

Keywords: Inverter, THD, SPWM, Matlab, Simulink, H-bridge.

\section{INTRODUCTION}

An Inverter converts DC power to AC power at the desired output voltage and frequency [1]. Inverters are widely used in industrial applications such as induction heating, adjustable speed AC motor drives, standby power supplies and uninterruptible power supplies [2]. The DC power input of inverter can be obtained from the existing power supply network or from a battery bank; solar pannel arrays and wind energy, fuel cell or other DC sources [3]. Inverters are broadly classified into two types namely voltage source inverter (VSI) and current source inverter (CSI) [4]. In VSI, inverter is fed by a dc source of small internal impedance. Looking from the ac side terminal, voltage level remains almost constant regardless of the load current drawn. Whereas in CSI, source current is predetermined and the load impedence determined the output voltage [5]. Uninterruptible power supply (UPS) is often used to supply an emergency AC power with low output voltage distortion, good disturbance rejection, as well as excellent voltage regulation, even under critical loading conditions. UPS systems can be off-line, where the load is connected to the utility under normal operation and emergency power provided by the UPS [6]. UPS can also be on-line if the batteries are always connected to the inverter such that the load is fed constantly by the battery source [7]. The technique of Pulse Width Modulation (PWM) is found reliable to be widely applied for generating appropriate gating signals for inverter switching and control. More recently, microcomputers and microcontrollers have dominated the design of control signals [8]. PWM technique is widely used in power electronics circuit design for controlling the electronic witches, this is because of the need for controlling voltage, frequency and harmonic content in the inverter stage [9].

\section{SINGLE PHASE FULL BRIDGE INVERTER}

Single phase Full bridge inverter is built from two half-bridge circuit sharing the same DC bus. Switching of the second and first leg is complimentary and is delayed by 180 degrees. The antiparallel freewheeling diodes discharges the reverse current which flows through the load during the OFF time. Figure 1 shows the block diagram of Single phase H-bridge inverter. 


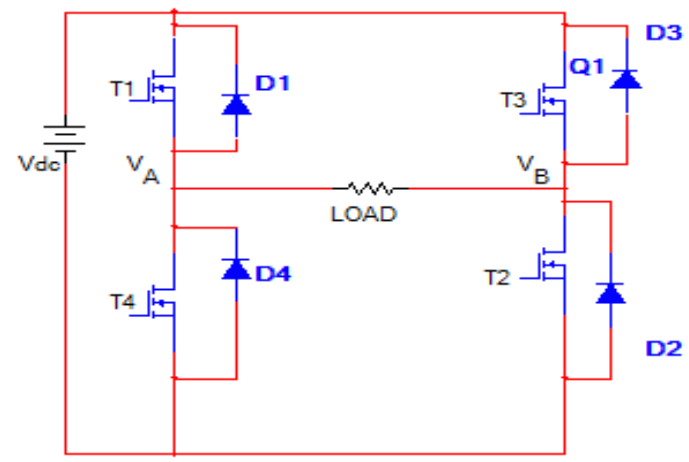

Figure 1: Single Phase H- Bridge Inverter

\section{SINGLE PHASE H-BRIDGE INVERTER CONTROL WITH UNIPOLAR VOLTAGE}

\section{SWITCHING}

In this scheme, the high frequency triangular carrier wave $(\mathrm{Vcr})$ is compared with two sinusoidal modulating signals (Vm and $\mathrm{Vm}$ ) having the same amplitude and a frequency of $50 \mathrm{~Hz}$. The two sinusoids are $180^{\circ}$ out of phase. The output is used to switch the two legs of the h-bridge inverter in a complementary fashion. The Schematic is shown in figure 2.

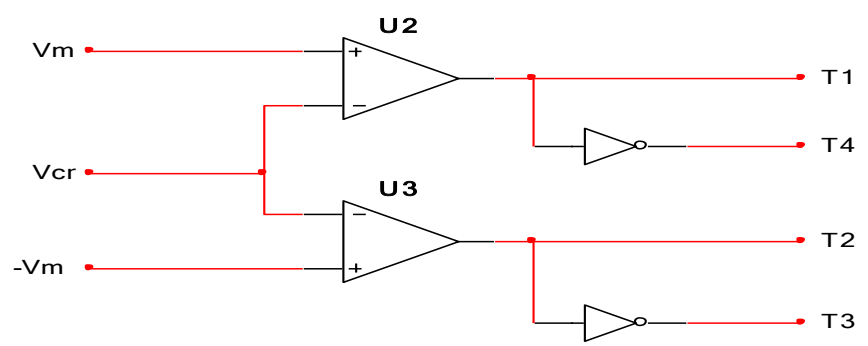

Figure 2: Unipolar SPWM generator

\subsection{SWITCHING RULES}

From the single phase $\mathrm{H}$-bridge inverter circuit, the following switching rules are deduced

Case 1: $\mathrm{T} 1, \mathrm{~T} 2, \mathrm{~T} 3, \mathrm{~T} 4$ Open, $\mathrm{Vab}=0 \Rightarrow$ Open Circuit

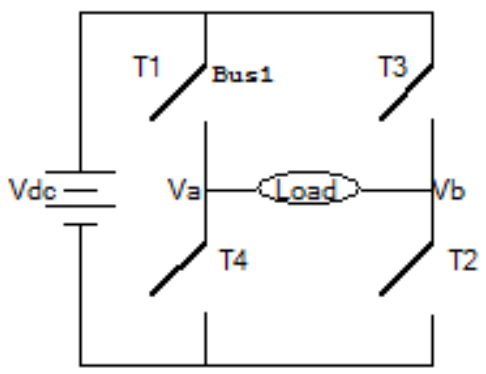

Case 2: T1\&T3 closed, T2\&T4 Open, Vab=0

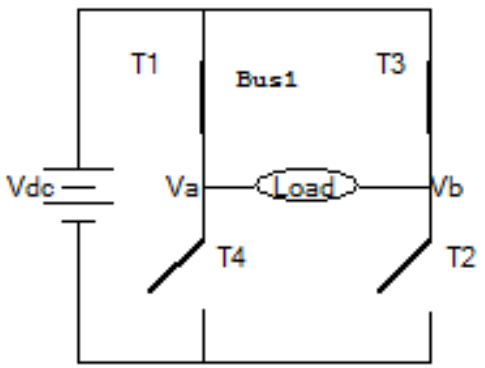




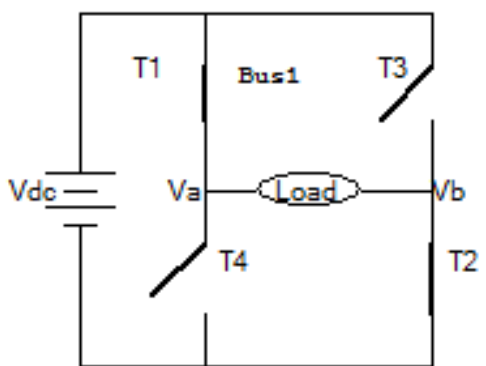

Case 5: T1\&T3 Open, T2\&T4 closed, Vab=0

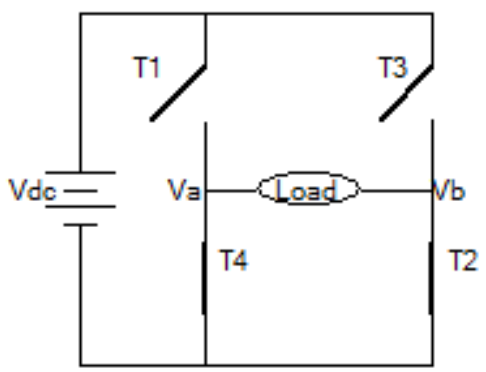

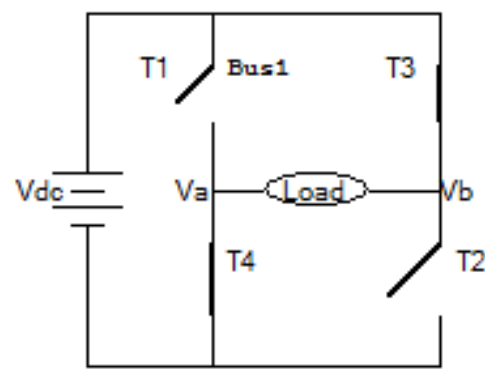

Case 6: $\mathrm{T} 1, \mathrm{~T} 2, \mathrm{~T} 3, \mathrm{~T} 4$ closed, Vab=0 $\Rightarrow$ Short Circuit

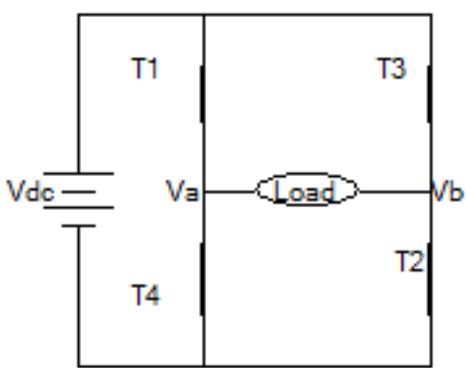

\subsection{SWICHING STATES}

The switches T1, T2, T3 and T4 in each branch is operated alternatively so that they are not in same state simultaneously. In practice they are both OFF for short perod of time called dead time to avoid short circuiting. The switches T1 and T2 or T3 and T4 operate in a pair to get the output. These bridges legs are switched such that the output voltage is shifted from one to another and hence the change in polarity occurs in voltage waveform. If the shift angle is zero, the output voltage is also zero and maximal when shift angle is $\pi$. If the On and Off state are represented in binary as $1 \mathrm{~s}$ and $0 \mathrm{~s}$, the switching table can be generated. Table 3 shows the switching table generated and figure 3 shows pole and line Voltage of single phase full bridge inverter.

Table 3: Switching Table for Single Phase Unipolar Voltage Inverter

\begin{tabular}{|c|c|c|c|c|}
\hline T1 & T2 & T3 & T4 & OUTPUT( $\mathbf{V}_{\text {dc }}$ ) \\
\hline 1 & $\mathbf{1}$ & $\mathbf{0}$ & $\mathbf{0}$ & Vab \\
\hline 0 & $\mathbf{0}$ & $\mathbf{0}$ & $\mathbf{0}$ & $\mathbf{0}$ \\
\hline 1 & $\mathbf{0}$ & $\mathbf{1}$ & $\mathbf{0}$ & $\mathbf{0}$ \\
\hline 0 & $\mathbf{1}$ & $\mathbf{0}$ & $\mathbf{1}$ & $\mathbf{0}$ \\
\hline 1 & $\mathbf{1}$ & $\mathbf{1}$ & $\mathbf{1}$ & $\mathbf{0}$ \\
\hline 0 & $\mathbf{0}$ & $\mathbf{1}$ & $\mathbf{1}$ & $\mathbf{- V a b}$ \\
\hline
\end{tabular}

\section{CIRCUIT MODEL USING SIMULINK BLOCK OF MATLAB}

The Circuit in figure 3 below shows the Simulink model of Single Phase SPWM Inverter With Unipolar Voltage Switching. An LC filter is used at the output to reduced the harmonic content to a level suitable for powering sensitive loads in UPS applications. Table 2 shows the Parameters used for the Inverter Model 

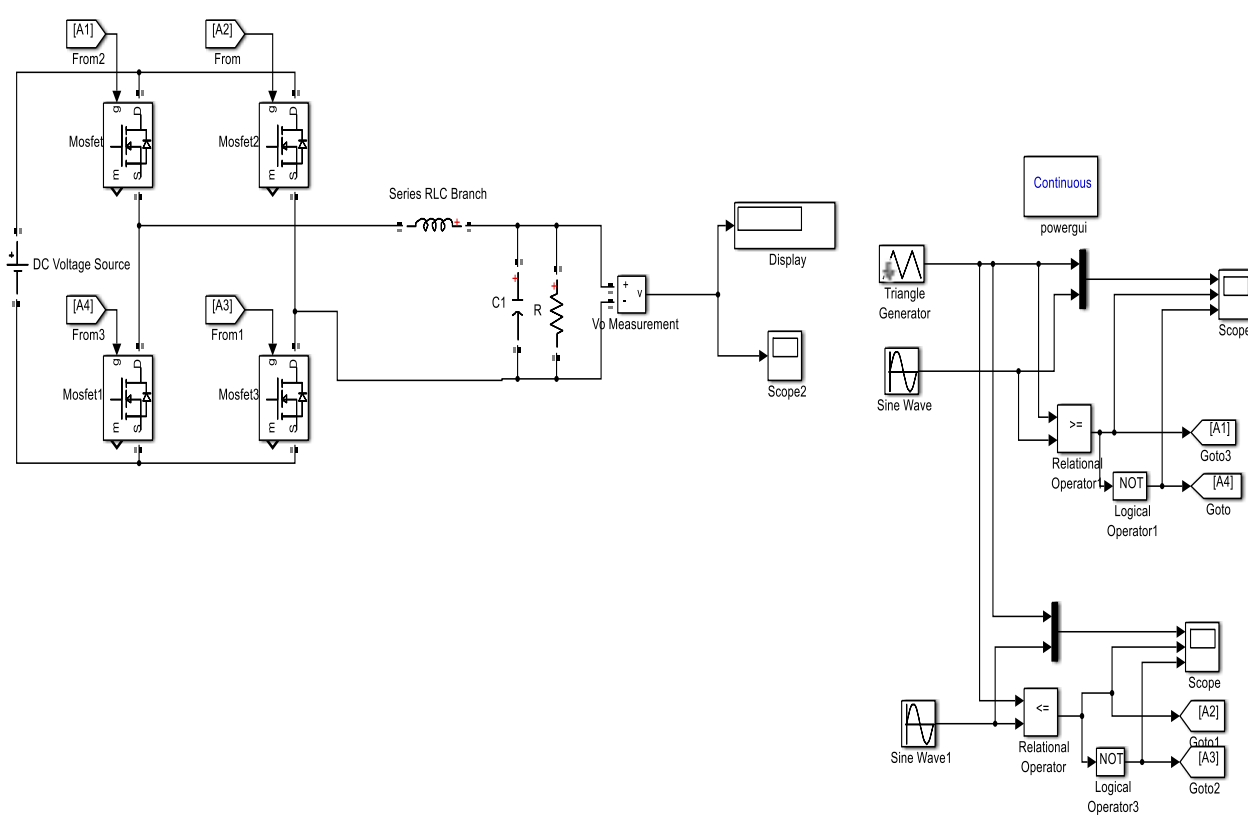

Figure 3: Simulink Circuit Model of Single Phase SPWM Inverter with Unipolar Voltage Switching

Table Two: Parameters used for the Inverter Model

\begin{tabular}{|l|l|}
\hline DC Link Voltage & $325 \mathrm{~V}$ \\
\hline Amplitude and frequency of the Triangular Wave Carrier $\left(\mathrm{V}_{\mathrm{cr}}\right)$ & $1 \mathrm{~V}, 20 \mathrm{kHz}$ \\
\hline $\begin{array}{l}\text { Amplitude and frequency of the Sine Wave modulationg signal } \\
(\mathrm{Vm})\end{array}$ & $0.8 \mathrm{~V}, 50 \mathrm{~Hz}$ \\
\hline Filter Capacitor $(\mathrm{C})$ & $180 \mu \mathrm{F}$ \\
\hline Inductor $(\mathrm{L})$ & $0.9 \mathrm{mH}$ \\
\hline
\end{tabular}

\section{SIMULATION RESULTS}

Table Three gives the simulation result of the output voltage, current, THD and computed power output of the Single phase SPWM Inverter with LC filter using varying load resistances.

Table Three: Output Voltage, Current, THD and Power Output

\begin{tabular}{|c|c|c|c|c|c|}
\hline Sl.N. & $\begin{array}{l}\text { Output } \\
\text { Voltage (V) }\end{array}$ & $\begin{array}{l}\text { Output } \\
\text { Current }(\mathbf{A})\end{array}$ & $\begin{array}{l}\text { Load } \\
\text { Resistance }(\boldsymbol{\Omega})\end{array}$ & $\begin{array}{l}\text { THD } \\
(\boldsymbol{\%})\end{array}$ & $\begin{array}{l}\text { Output } \\
\text { Power }(\mathbf{W})\end{array}$ \\
\hline 1 & 236.5 & 3.92 & 10 & 2.76 & 927 \\
\hline 2 & 238.0 & 3.40 & 20 & 3.44 & 809 \\
\hline 3 & 238.6 & 3.11 & 30 & 3.44 & 742 \\
\hline 4 & 239.2 & 2.93 & 40 & 3.90 & 700 \\
\hline 5 & 239.5 & 2.34 & 50 & 4.22 & 560 \\
\hline
\end{tabular}

Figure 4 is the circuit simulation result of single phase sinusoidal pulse width modulation inverter (SPWM) with unipolar voltage switching without Filter. The waveform shows a modified sine wave of constant peak-to-peak value. The Fast Fourier Transform 
(FFT) analysis window shows the fundamental voltage of $283.4 \mathrm{~V}$ at the frequency of $50 \mathrm{~Hz}$. Total harmonic distortion (THD) is at $64.42 \%$ after 25 consecutive cycles. Without filtering, this high harmonic content cannot be suitable to power sensitive loads.

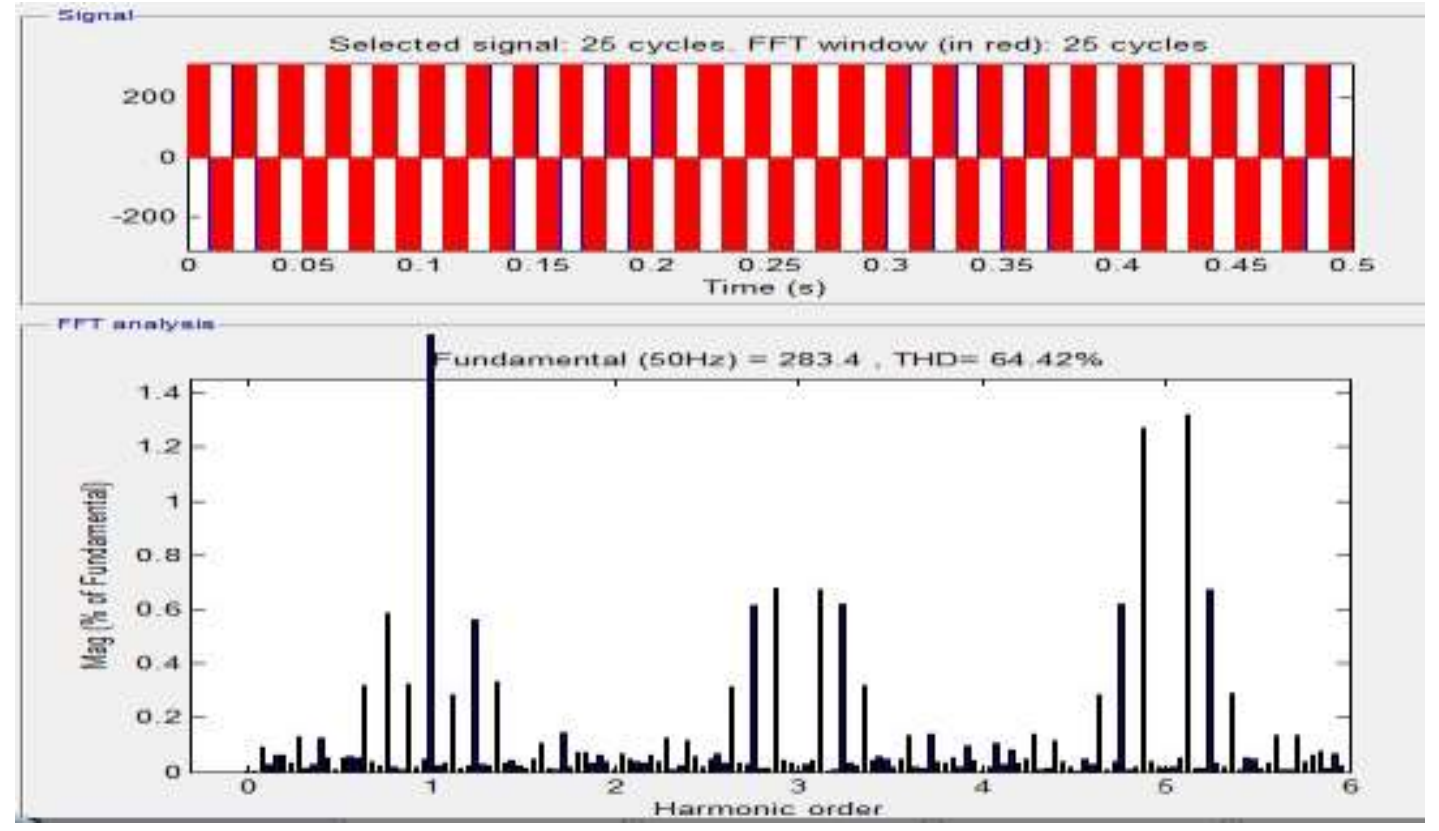

Figure 4: Output Waveform and Harmonic Spectrum of the Simulated Inverter Without Filter

Figure 5 is the simulation result of the single phase SPWM inverter with LC filter. With the incorporation of LC filter, the waveform is sinusoidal. The FFT analysis reveals a pure sine wave of fundamental voltage of $236.5 \mathrm{~V}$ and harmonic content drastically reduced to $2.76 \%$ when the load resistance of $10 \Omega$ was applied.

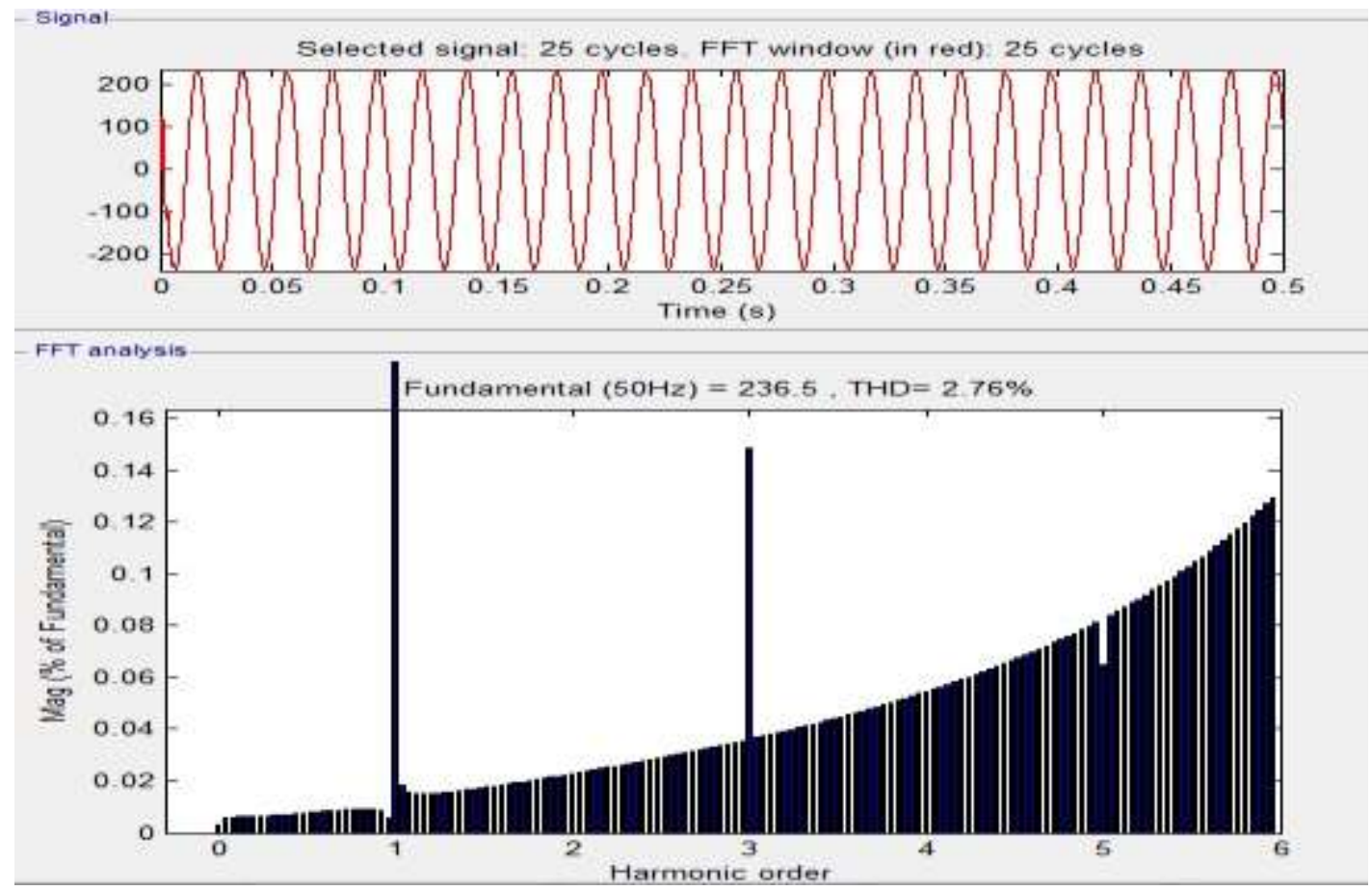

Figure 5: Output Waveform and Harmonic Spectrum of the Simulated Inverter with LC Filter at $10 \Omega$ load.

Figure 6 is the simulation result showing the fundermental voltage and THD voltage rised to $238 \mathrm{~V}$ when the load resistance of $20 \Omega$ was applied, the THD level increased to $3.44 \%$. With load varietion however, the transient response occur at less than $0.01 \mathrm{~s}$. 
International Journal of Advances in Scientific Research and Engineering (ijasre), Vol 8 (1), January -2022

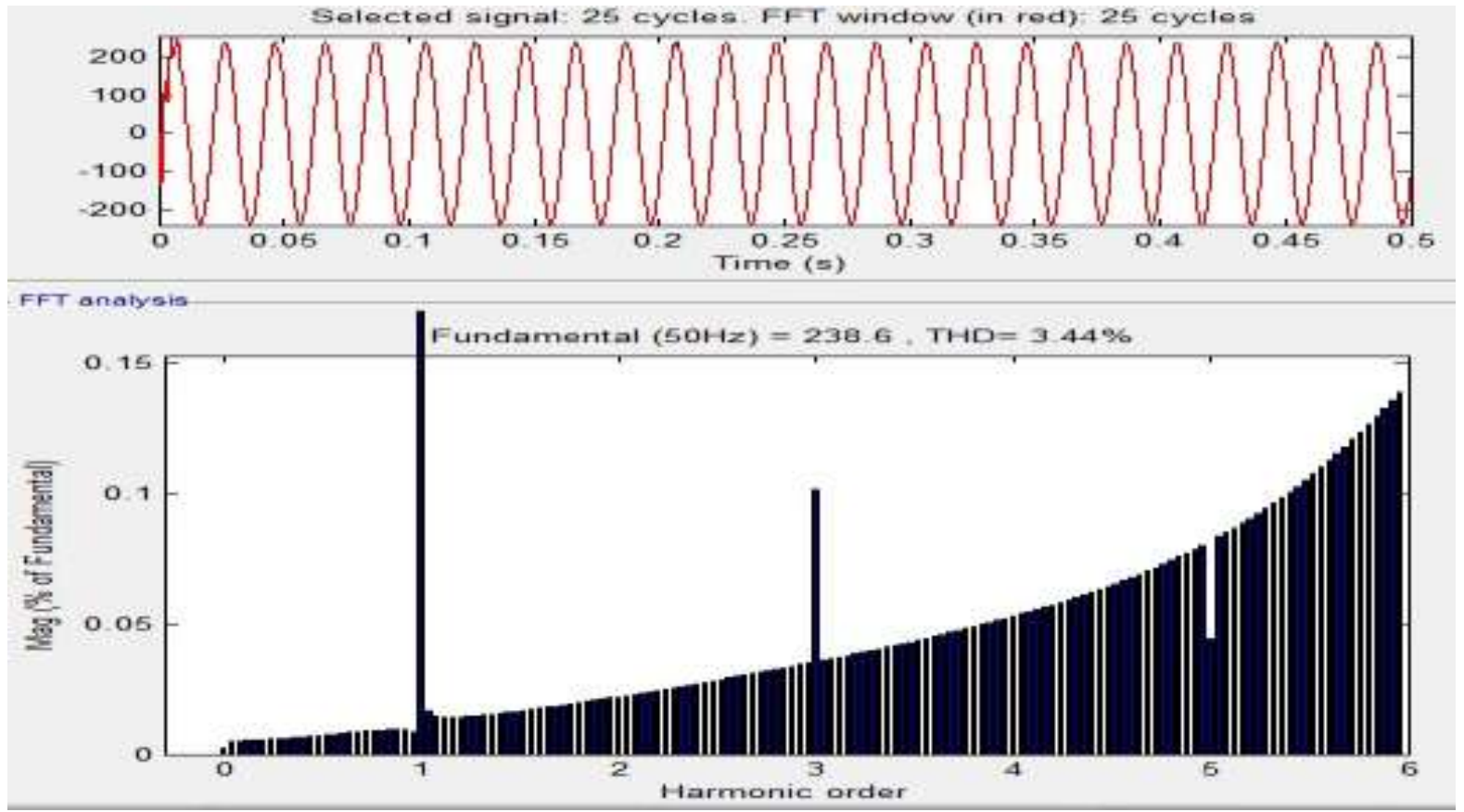

Figure 6: Output Waveform and Harmonic Spectrum of the Simulated Inverter with LC Filter at $20 \Omega$ load

Figure 7 is the simulation result showing the fundermental voltage and THD voltage further increased to $239.2 \mathrm{~V}$ when the load resistance of $30 \Omega$ was applied, the THD level increased to $3.90 \%$. With the increase in load varietion however, the transient response occur at $0.01 \mathrm{~s}$ wih the overshoot of $5 \%$
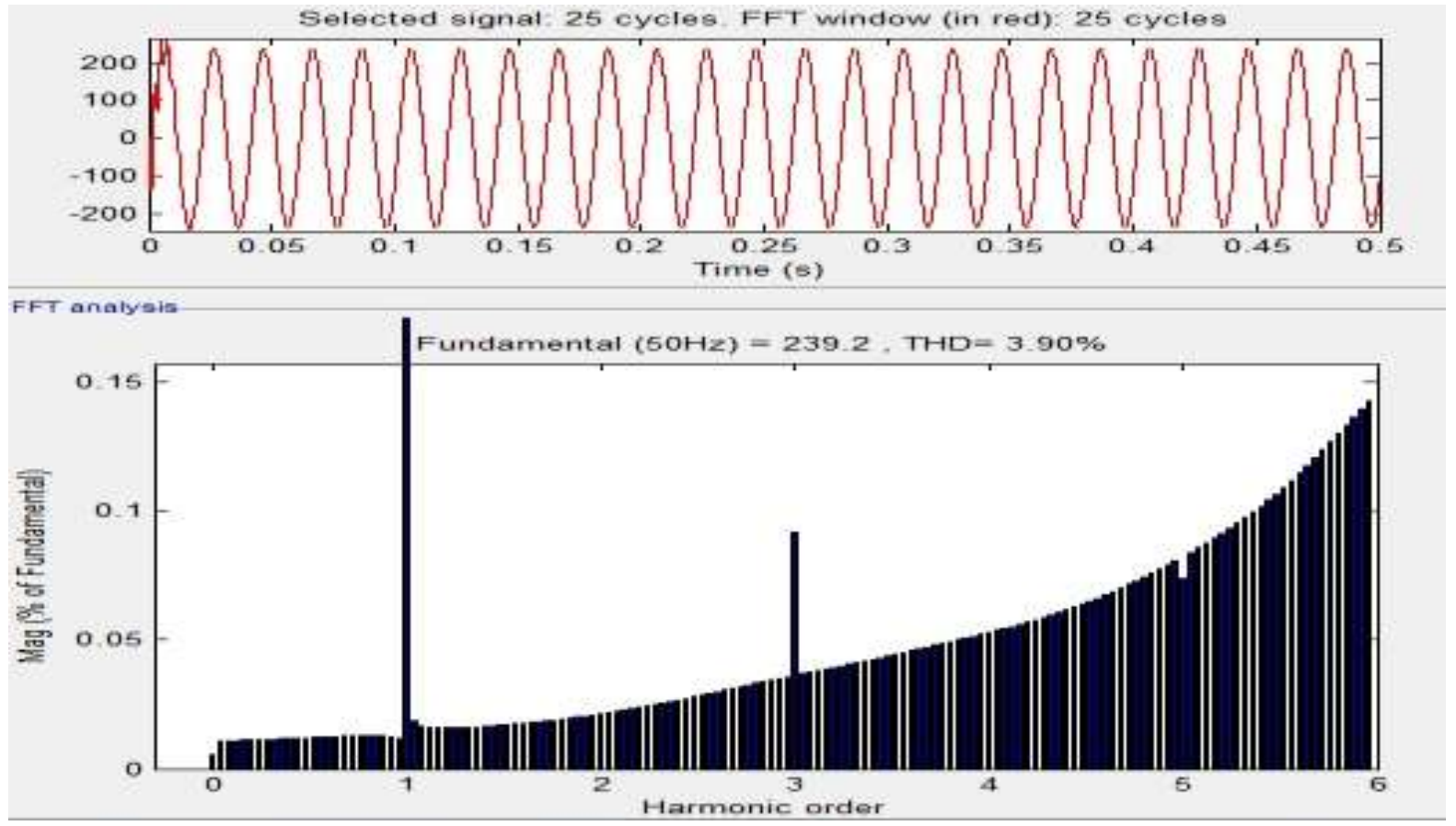

Figure 7: Output Waveform and Harmonic Spectrum of the Simulated Inverter with LC Filter at $30 \Omega$ load

Figure 8 is the simulation result of voltage waveform showing the fundermental voltage and THD voltage further increased to $239.5 \mathrm{~V}$ when the load resistance of $40 \Omega$ was applied, the THD level increased to $4.22 \%$. With the increase in load varietion however, the transient response occur at $0.015 \mathrm{~s}$ wih the overshoot of $5.3 \%$ 
International Journal of Advances in Scientific Research and Engineering (ijasre), Vol 8 (1), January -2022

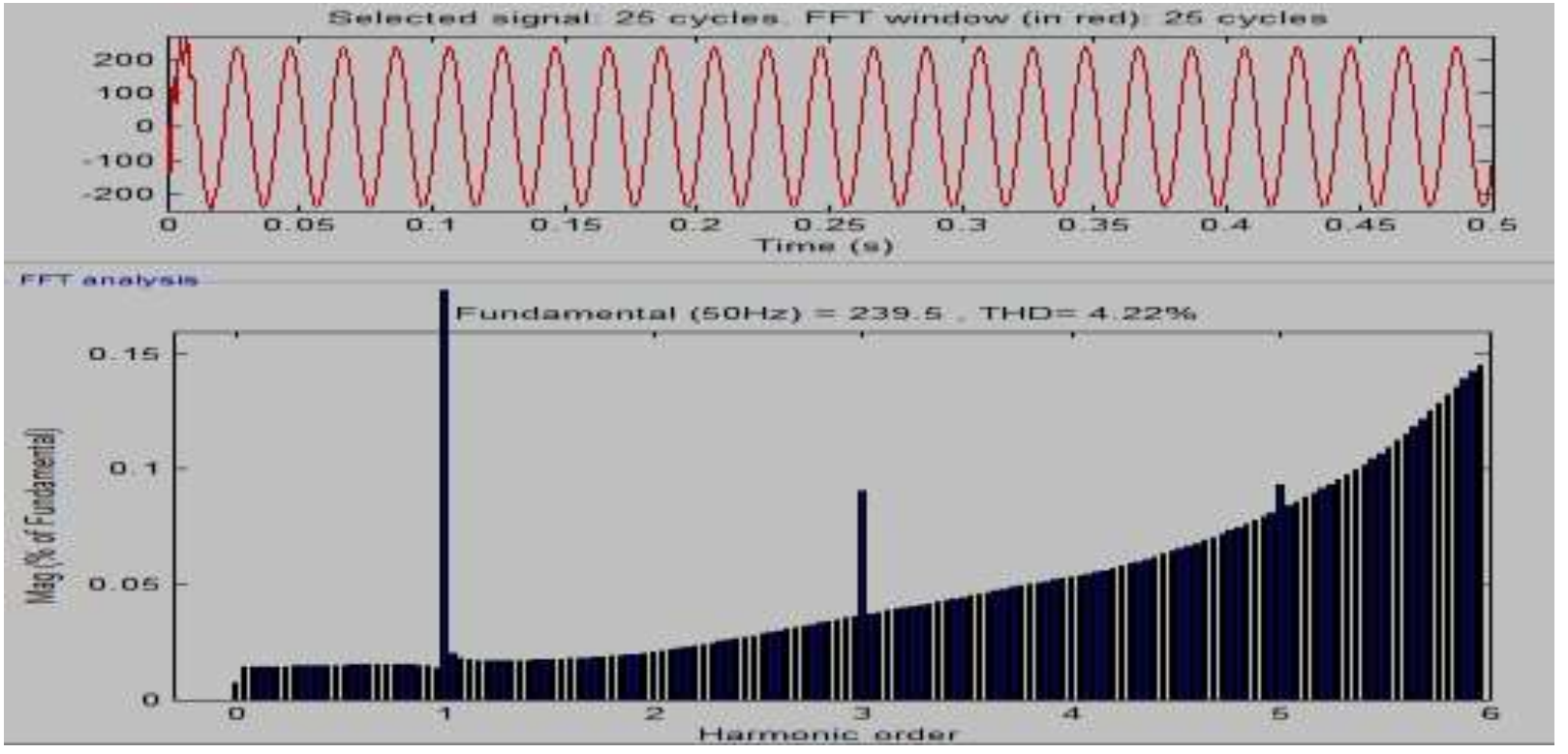

Figure 8: Output Waveform and Harmonic Spectrum of the Simulated Inverter with LC Filter at $40 \Omega$ load

Figure 9 is the simulation result of voltage waveform showing the fundermental voltage and THD voltage further increased to $239.7 \mathrm{~V}$ when the load resistance of $50 \Omega$ was applied, the THD level increased to $4.46 \%$. With the increase in load varietion however, the transient response occur at $0.016 \mathrm{~s}$ wih the overshoot of $5.6 \%$

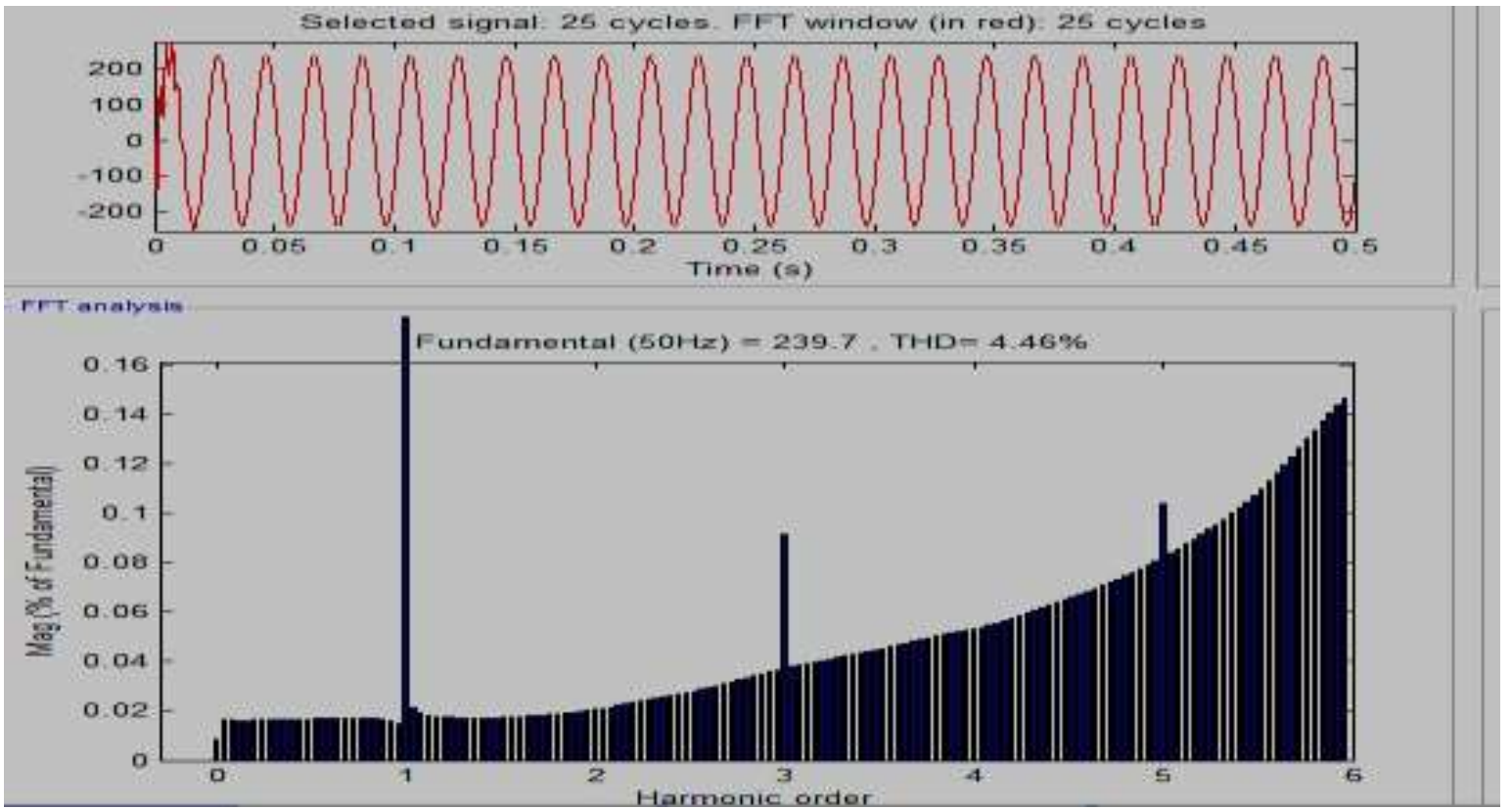

Figure 9: Output Waveform and Harmonic Spectrum of the Simulated Inverter with LC Filter at $40 \Omega$ load

Figure 10 is the Oscilloscope waveform of the single phase SPWM Inverter without Filter. Figure 11 show the filtered waveform when a passive LC filter was applied. The output voltage is sinusoidal with root means square value of $233 \mathrm{~V}$. This voltage is suitable enough for powering sensitive loads. Figure 12 is the complete experimental setup of the system. 
International Journal of Advances in Scientific Research and Engineering (ijasre), Vol 8 (1), January -2022

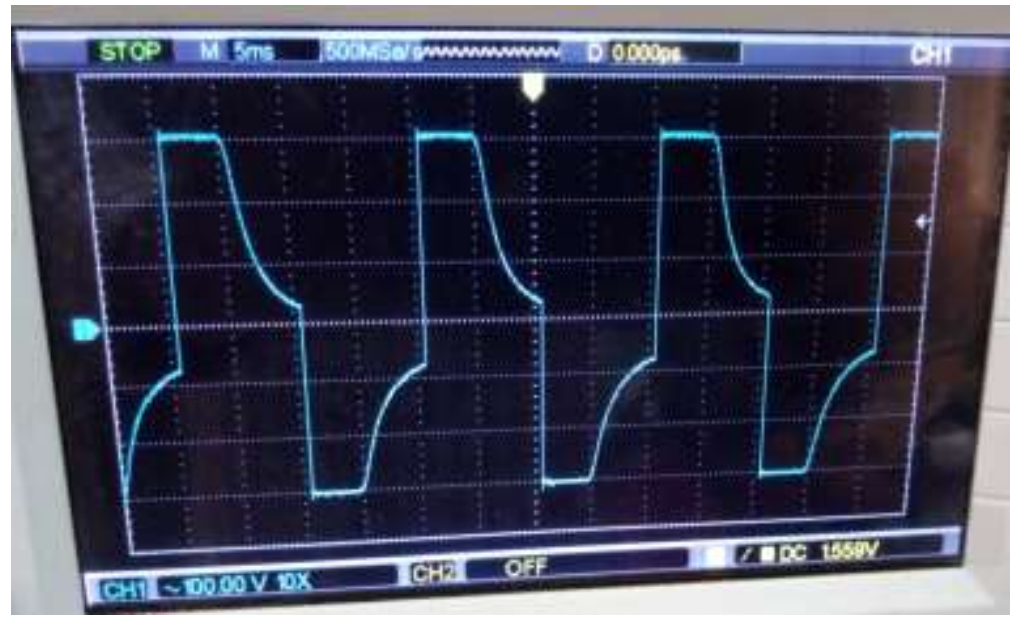

Figure 10 Oscilloscope waveform of the single phase SPWM Inverter without Filter

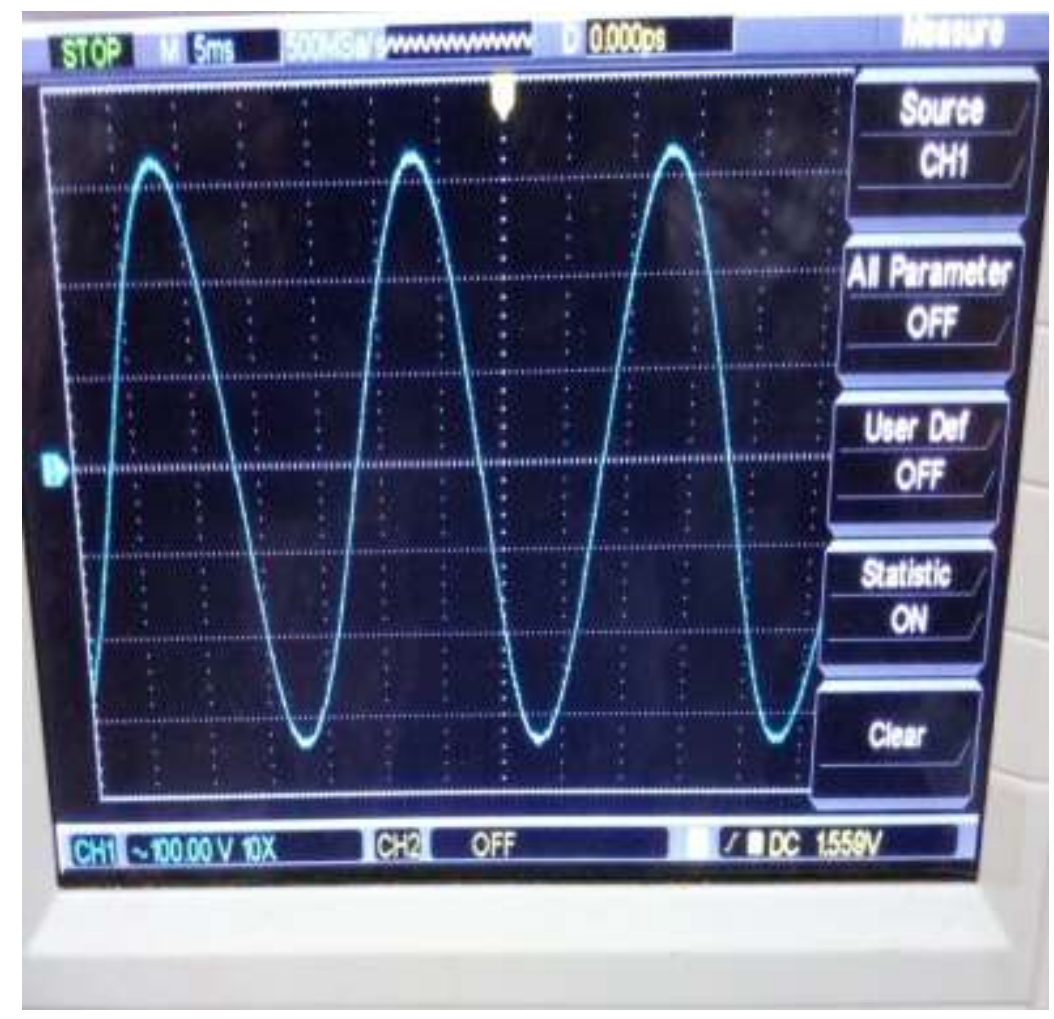

Figure 11: Oscilloscope View Of The Filtered single phase SPWM Output 


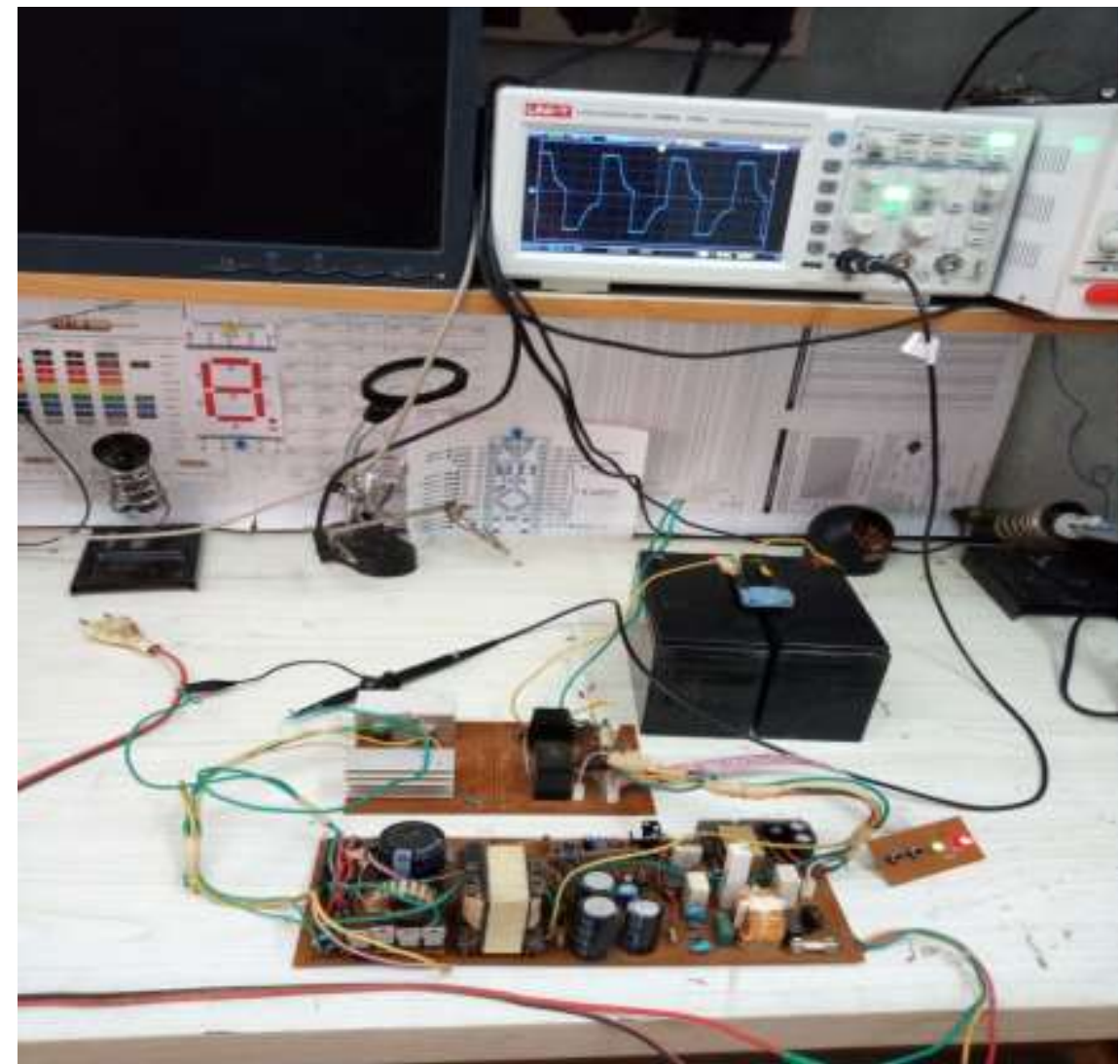

Figure 12: Complete Hardware setup

\section{CONCLUSION}

From the results presented in figures 5 and 9 , it shows that sinusoidal pulse width modulation with unipolar voltage switching technique can offer reduced harmonic distortion in single phase inverters to as low as $2.7 \%$ when filter elements are carefully selected. However, a voltage feed back controller is needed to main a constant output voltage for stability as such, the system can be used for wide range of applications such as in UPS system.

\section{REFERENCES}

1. Maria D, Tzong S, Aristide T, Javad M. (1998). " A Review of Soft-switched DC-AC Converter," IEEE trans. On Industry Appl, 43(4) pp 847-858,

2. Wang, S (2006). Research of Novel Three-phase Inverter and its Modulation Technique" International Nature and Science, 4(3), 2006

3. Tolbert L. (2008). Multilevel converter as a unity interface for renewable energy system. IEEE proceedings, Power Engineering Society Summer Meeting, Seattle pp 1271-1274

4. Anas, M. (2014). Performance analysis of single phase inveretr” International Journal Of Modern Engineering Research. (4) 4: $1-7$

5. Ismail, (2006). Development of a Single Phase SPWM Microcontroler -Based Inverter. First International Power and Energy Conference PEC. Putra jaya, Malaysia: IEEE pp 437

6. Abdelazin, S. (2014). Intelligent UPS inverter control design using microcontroller. Journal of Energy Technologies and Policy. 4 (2): 34-47

7. Pacheco M. ( 2005). An online UPS System with power factor correction and output voltage stabilization, IEEETrans. Power Electron. 20( 5): pp. 1109-1117 
8. Nazmul, I.R. (2012). Sinusoidal PWM Signal Generation Technique for Three Phase Voltage Source Inverter with Analog Circuit \& Simulation of PWM Inverter for Standalone Load \& Micro-grid System'. International Journal Of Renewable Energy Research. 3 (3)

9. Samier I.A (2014). Performance analysis of SPWM and SVPWM inverters Fed induction Motor. International journal of computer applications ISSN 0975-8887 Vol 4 No5 January 2014. 